\title{
Atypical hand-foot-and-mouth disease
}

\author{
Adam J. Hoffmann MD, Meriem Latrous MD, Joseph M. Lam MD
}

- Cite as: CMAJ 2020 January 20;192:E69. doi: 10.1503/cmaj.191100

A 3-year-old boy presented to the pediatric emergency department with a 4-day history of a progressive papulovesicular rash that started on his buttock and involved his legs, hands, feet, axilla and oropharynx (Figure 1). Ten days earlier, he had been diagnosed with pharyngitis and prescribed amoxicillin. The patient had been in contact with other children with pharyngitis at day care. In the emergency department, he was febrile, but appeared clinically well. Because of the concern about eczema herpeticum, he was admitted and given intravenous acyclovir. A lesional polymerase chain reaction (PCR) swab was positive for enterovirus, and negative for herpes simplex virus and varicella-zoster virus. Acyclovir was discontinued, and the patient was discharged home with follow-up in pediatric dermatology. The patient's sister subsequently developed a sore throat and intraoral lesions.

We diagnosed this patient with atypical hand-foot-and-mouth disease, a manifestation of enterovirus infection that is becoming more widely recognized. ${ }^{1,2}$ It is most commonly characterized by widespread vesiculobullous eruptions or erosions that are generally painless in a child who otherwise appears well. ${ }^{1,2}$ Other manifestations include an eczema herpeticum-like eruption in areas of atopic dermatitis, a Gianotti-Crosti-like eruption that spares the torso, or a petechial or purpuric eruption. ${ }^{2}$ Children with atypical hand-footand-mouth disease are usually younger than 5 years. ${ }^{2}$ It is diagnosed clinically but can be confirmed with a lesional PCR swab for enterovirus. Coxsackievirus $A 6$ is the most common pathogen causing atypical hand-foot-and-mouth disease. ${ }^{1,2}$

It is important to differentiate atypical hand-foot-and-mouth disease from other conditions, such as eczema herpeticum, varicella-zoster virus or bullous impetigo, as atypical hand-footand-mouth disease is self-limiting and requires only supportive therapy. ${ }^{1,2}$ Prompt recognition can reduce unnecessary treatment and hospital admission. ${ }^{1,2}$ Patients are highly contagious and should be counselled on appropriate hand hygiene as well as staying home from school or day care. ${ }^{2}$ The exanthem or enanthem usually resolves within 1-2 weeks, and parents should be made aware of the potential for delayed onychomadesis (shedding of the nails), and palmar and plantar desquamation.,

\section{References}

1. Feder HM, Bennett N, Modlin JF. Atypical hand, foot, and mouth disease: a vesiculobullous eruption caused by Coxsackie virus A6. Lancet Infect Dis 2014;14:83-6.

2. Mathes EF, Oza V, Frieden IJ, et al. "Eczema coxsackium" and unusual cutaneous findings in an enterovirus outbreak. Pediatrics 2013;132:e149-57.

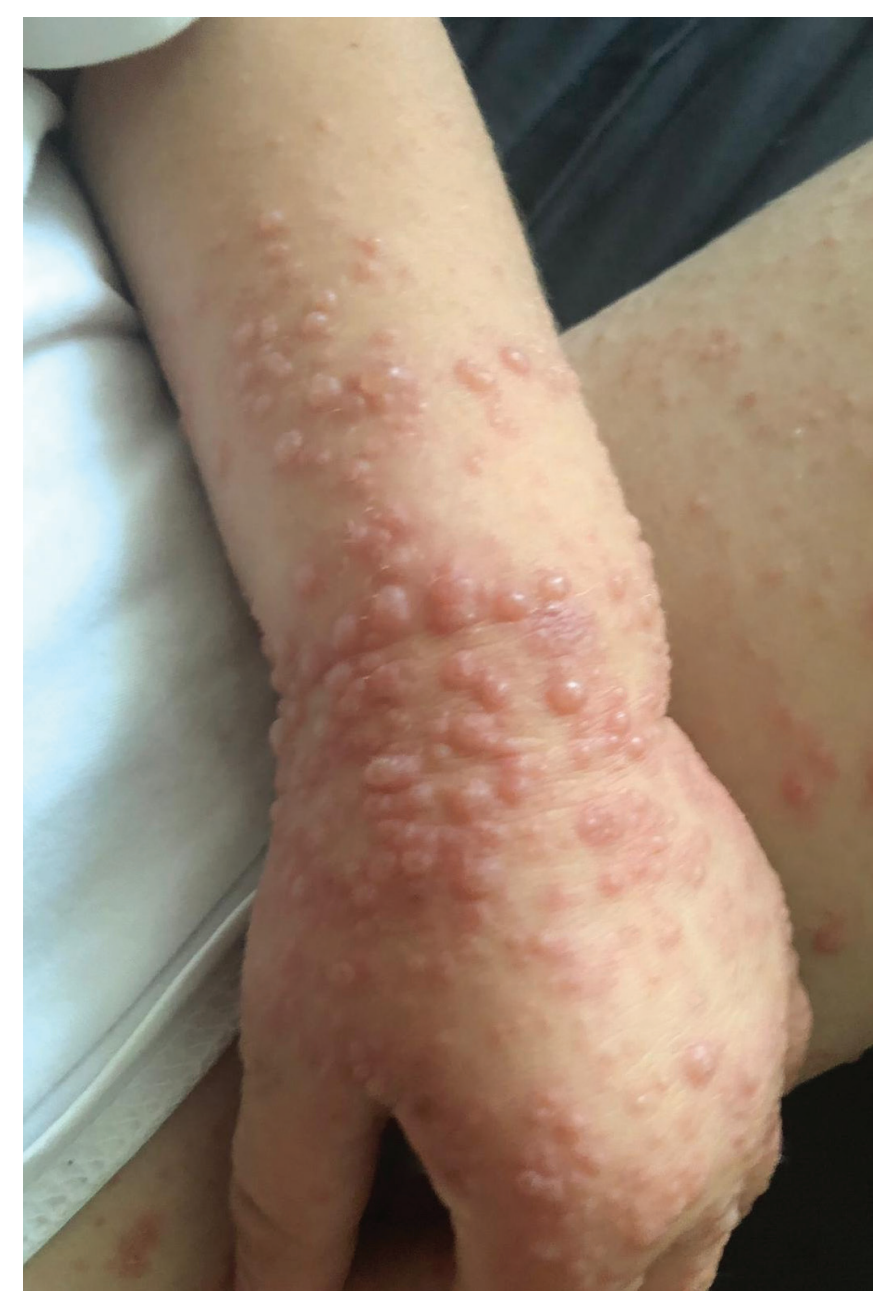

Figure 1: Clustered erythematous vesicles over the dorsum of the left hand of a 3-year-old boy.

\section{Competing interests: None declared.}

This article has been peer reviewed.

The authors have obtained parental consent.

Affiliations: Departments of Pediatrics (Hoffmann, Latrous, Lam), and of Dermatology and Skin Science (Lam), University of British Columbia, Vancouver, BC

Correspondence to: Joseph Lam, joseph.mc.lam@gmail.com 